\title{
KEPEMIMPINAN NEHEMIA DAN RELEVANSINYA DALAM PENGELOLAAN PERGURUAN TINGGI KEAGAMAAN KRISTEN DI INDONESIA
}

\author{
Nasokhili Giawa \\ Sekolah Tinggi Teologi Jaffray Jakarta \\ nsgiawa@yahoo.com
}

\begin{abstract}
Leadership is an instrument to achieve the vision, mission, goals, targets, and success of an organization, so we need a good leadership. With good leadership a leader can achieve goals and be able to manage conflicts / obstacles that may occur in the leadership process. From this problem the authors conducted an analysis of the concept of Nehemiah's leadership, because Nehemiah was a leader who was able to rebuild the wall of Jerusalem that had been damaged. The author analyzes the biblical texts and various literatures relevant to the topic. The analysis shows that Nehemiah's leadership is visionary and inspirational leadership. The leadership is relevant to the management of Christian Religious Colleges in Indonesia (PTKKI) because it is built on the foundation of true spirituality, guided by a clear vision, a good management process.
\end{abstract}

Keywords: Jerusalem's walls, leaders, leadership, mission, vision

\begin{abstract}
Abstrak
Kepemimpinan merupakan instrumen untuk mencapai visi, misi, tujuan, target, dan kesuksesan suatu organisasi, sehingga diperlukan sebuah kepemimpinan yang baik. Dengan kepemimpinan yang baik seorang pemimpin dapat mencapai tujuan serta mampu memanajemeni konflik/rintangan yang mungkin terjadi dalam proses kepemimpinan itu. Dari masalah tersebut penulis melakukan analisis terhadap konsep kepemimpinan Nehemia, karena Nehemia merupakan tokoh pemimpin yang mampu membangun kembali tembok Yerusalem yang telah rusak. Penulis melakukan analisis pustaka terhadap teks Alkitab dan berbagai literatur yang relevan dengan topik tersebut. Dari hasil analisis tampak jika kepemimpinan Nehemia adalah kepemimpinan yang visioner dan inspiratif. Kepemimpinan tersebut relevan dengan pengelolaan Perguruan Tinggi Keagamaan Kristen di Indonesia (PTKKI) karena dibangun di atas dasar spiritualitas yang benar, dituntun oleh visi yang jelas, dan proses manajemen yang baik.
\end{abstract}

Kata Kunci: tembok Yerusalem, pemimpin, kepemimpinan, misi, visi 


\section{Pendahuluan}

Harapan terciptanya kepemimpinan yang baik dan benar merupakan dambaan setiap organisasi termasuk organisasi yang mengurus masalah kerohanian (gereja). Perlu diketahui bahwa sebagaimana organisasi pada umumnya, gereja tidak terlepas dari pergumulan kepemimpinan. Dalam pengamatan Sendjaya, salah seorang pakar kepemimpinan, menyatakan bahwa, "Gereja pun tidak imun dari krisis kepemimpinan. Gereja yang seharusnya menghasilkan pemimpin yang tinggi iman, tinggi ilmu, dan tinggi pengabdian malah terkontaminasi dengan berbagai masalah kepemimpinan." 1 Hal ini dihubungkan dengan penelitian George Barna berkenaan dengan kepemimpinan yang "menyimpulkan hasil studinya selama 15 tahun tentang kehidupan gereja secara global dengan konklusi sebagai berikut: Gereja telah kehilangan pengaruhnya karena absennya kepemimpinan yang efektif."2

Dalam pengamatan dan kesimpulan Sendjaya, yang terlibat dalam gerakan pendidikan di lingkup pendidikan tinggi Kristen di Indonesia, baik itu secara struktural maupun fungsional, gelisah. Ia menyatakan, "Banyak masalah akut dan kronis yang melumpuhkan berbagai jenis organisasi di atas disebabkan atau terkait dengan krisis kepemimpinan. Terlalu banyak organisasi yang dipimpin oleh orang-orang yang kurang diperlengkapi dengan kompetensi kepemimpinan yang mapan. Beberapa dari mereka bahkan memiliki cacat karakter. Integritas seringkali dikorbankan demi kelanggengan ambisi pribadi. Pada saat yang bersamaan, dampak dari aksi kepemimpinan mereka menjalar seperti kanker dari dalam organisasi, dan melumpuhkannya secara perlahan." 3 Sekali lagi, dalam konteks ini, Sendjaya berpendapat bahwa krisis kepemimpinan adalah sebuah masalah yang krusial. Namun, ada masalah yang lebih krusial, dan sekaligus urgen, yaitu masalah kepedulian. Banyak orang yang tidak peduli terhadap fakta bahwa kita tidak memiliki figur dan sistem kepemimpinan yang baik. Apalagi kepemimpinan yang biblikal. ${ }^{4}$

Kepemimpinan yang biblikal adalah kepemimpinan berpaut dan bersumber pada firman Allah. Pendekatan dan contoh-contoh konkrit untuk memimpin telah diletakkan oleh Alkitab. Terkait dengan hal ini, Sendjaya menambahkan, "Semakin dekat prinsip, pola, dan praktik kepemimpinan sebuah organisasi kepada nilai-nilai Alkitab, semakin besar kemungkinan prinsip, pola, dan praktik kepemimpinan tersebut menghasilkan sistem yang transparan (accountable) dan langgeng (sustainable). Semua dimensi ini merupakan bagian penting dan urgen yang perlu dihadirkan dalam kepemimpinan yang biblikal.

Dalam konteks kepemimpinan yang biblikal, Nehemia hadir sebagai rujukan dan teladan yang memberi inspirasi, pengertian, arah, konsep, bahkan batasan berkenaan dengan kepemimpinan itu sendiri. Ia termasuk pemimpin yang berhasil. Harus diakui bahwa kepemimpinan Nehemia menarik untuk dikaji dan tetap relevan dengan kebutuhan pengelolaan Perguruan Tinggi Keagamaan Kristen di Indonesia.

Pertanyaan yang perlu dijawab melalui tulisan ini, apakah nilai, prinsip, dan gaya kepemimpinan Nehemia mampu menjawab kebutuhan PTKKI? Dalam tulisan ini yang dimaksud dengan kepemimpinan adalah pengaruh yang dirujuk dari kepemimpinan Nehemia bagi pencapaian tujuan organisasi, yakni dalam pengelolaan perguruan tinggi keagamaan kristen di Indonesia.

${ }^{1}$ Sendjaya, Kepemimpinan Kristen: Konsep, Karakter, Kompetensi: Menjadi Pemimpin Kristen Yang Efektif Di Tengah Tantangan Arus Zaman (Yogyakarta: Kairos, 2004).

2Sendjaya.

3Sendjaya.

${ }^{4}$ Sendjaya. 


\section{Metode Penelitian}

Tulisan ini menggunakan metode penelitian kualitatif yang didasarkan pada proses internalisasi dan kajian kepemimpinan terutama kepemimpinan salah seorang tokoh atau pemimpin besar dalam konteks Perjanjian Lama. Secara khusus, peneliti melakukan kajian tentang kepemimpinan Nehemia. Ini akan lebih banyak menggunakan pendekatan biblis dan penelitian kepustakaan. Mengingat karena kitab Nehemia terlalu luas, sistematika pemaparan tulisan ini, pertama-tama dimulai dengan memahami pengertian dan perbedaan pemimpin serta kepemimpinan. Kedua, mengenal latar belakang dan panggilan Nehemia sebagai pemimpin efektif dan produktif. Pada bagian terakhir, peneliti berupaya menggali prinsip dan nilai-nilai kepemimpinan Nehemia dalam teks dan konteks. Kemudian menghubungkan relevansinya di tengah-tengah pelayanan Perguruan Tinggi Keagamaan Kristen di Indonesia. Tulisan ini dipaparkan secara deskriptif-hermeneutis untuk menemukan prinsip yang relevan dan bermanfaat bagi kebutuhan kepemimpinan PTKKI masa kini.

\section{Hasil dan Pembahasan}

Perlu diakui bahwa kepemimpinan Nehemia memiliki daya tarik tersendiri dan relevan sepanjang zaman. Dalam buku Tafsiran Wycliffe menyatakan kekaguman terhadap kepemimpinan Nehemia. Penulis atau editor mengakui dengan menyatakan, "Harus dikemukakan bahwa tidak ada bagian dalam Kitab Perjanjian Lama yang lebih hebat memberi kita dorongan untuk mengabdi serta semangat yang kuat untuk melakukan pekerjaan Tuhan daripada Kitab Nehemia. Teladan dari kerinduan Nehemia pada kebenaran firman Allah, apa pun harga atau akibatnya, merupakan teladan yang sangat dibutuhkan saat ini." 5 Kepemimpinan Nehemia patut ditiru. Ia memimpin dengan melibatkan hati nurani, jiwa, dan raga. Ia melibatkan suasana lingkungan yang kondusif. Ia melibatkan orang laindan ia berbagi kepemimpinan (sharing leadership). Prinsip pendelegasian dalam kepemimpinan Nehemia berjalan dengan sangat baik. Ia memanajemeni kekuatan sumber daya manusia menjadi kekuatan bersama. Berdasarkan prinsip ini, semangat kebersamaan dan prinsip kolaboratif sangat diperlukan sehingga tidak terkesan atau cenderung hanya maju dan menikmati sendiri.

Nehemia adalah seorang pemimpin yang transformatif. Pengalaman pekerjaan yang tampak sederhana, tetapi memberi warna tersendiri pada zamannya. Sebagaimana diketahui dan dicatat oleh Alkitab bahwa ia bertugas menyediakan anggur untuk raja setiap hari (Nehemia 1:11, 2:1). Ada dua tugas utama yang diembannya:6 Tugas pertama, memimpin sekelompok umat Yahudi yang pulang ke Yerusalem, mengawasi pembangunan kembali tembok-tembok Yerusalem, dan menentukan keluarga-keluarga mana saja yang boleh tinggal di dalam kota. Tugas kedua, mencanangkan sejumlah pembaruan sosial dan politik di antara orang Yahudi, termasuk menegakkan ibadat yang benar kepada Allah (Nehemia 13:4-31). Nehemia tidak hanya sekadar membawakan minuman anggur, tetapi dia juga adalah orang yang pertama kali mencicipi minuman anggur itu untuk memastikan bahwa minuman itu tidak mengandung racun. Sesungguhnya tugas ini bukanlah tugas biasa karena sangat berbahaya bagi keselamatan hidup yang bersangkutan. Tetapi, justru inilah yang membuat Nehemia mendapat kepercayaan penuh dari raja. Tentu saja, dengan menjaga kepercayaan (integritas diri), menjadi modal berharga bagi Nehemia-apakah disadari atau tidak-yang kemudian ia mendapat perhatian penuh dari raja; dipedulikan oleh

\footnotetext{
${ }^{5}$ Charles F. Pfeiffer and Everett F. Harrison, The Wycliffe Bible Commentary: Tafsiran Alkitab Wycliffe (Malang: Gandum Mas, 2007), 1163.

${ }^{6}$ Alkitab Edisi Studi (Jakarta: Lembaga Alkitab Indonesia, 2014), 732.
} 
raja; dikasihani; dan bahkan mendapatkan kesempatan istimewa untuk mewujudkan visi dan misi besarnya.

Hak istimewa yang didapatkan oleh Nehemia mustahil bisa terwujud bila tidak membuktikan integritas dirinya sebagai pemimpin yang baik dan melayani dengan hati. Karena itu, diharapkan agar melalui pendekatan, gaya, dan prinsip baik yang tersurat maupun yang tersirat dalam kepemimpinan Nehemia dapat menjadi rujukan yang perlu diejawahtahkan dalam tugas dan pengabdian bersama di lingkungan PTKKI. Perlu meniru apa yang patut ditiru dan mengadopsi gagasan-gagasan positif dari kepemimpinan Nehemia sehingga PTKKI dapat berkontribusi positif dalam menghadirkan shalom Allah di tengah-tengah dunia ini, secara khusus dalam konteks pendidikan di Indonesia. Berkaca pada tulisan Elia Tambunan, mengungkapkan fakta sebagai berikut: kedigdayaan pendidikan Kristen jika ditilik sekarang seakan menempuh jalan bengkok. Apalagi, itu jika dibandingkan dengan pendidikan Islam. Setelah 73 tahun Kristen memiliki departemen yang membimbing. Itu dihitung mundur dari tahun 2019 sekarang kepada 3 Januari 1946 saat Kementrian Agama RI dibentuk. Ironisnya, kualitas pendidikan Kristen masih lebih rendah jika disandingkan dengan institusi pendidikan agama Islam seperti IAIN dan UIN dan pendidikan tingga agama Islam swasta lain. ${ }^{7}$ Ulasan ini memberikan gambaran problematika PTKKI serta pentingnya implementasi kepemimpinan Nehemia dalam perkembangan PTKKI.

\section{Pengejawantahan Visi Berbasis Permasalahan}

Banyak pakar yang memberi rumusan dan definisi tentang visi, tetapi sesungguhnya visi itu adalah kerinduan yang mendalam kepada Tuhan dan mengimani hal itu dapat terjadi. Kerinduan ini diwujudkan dalam sikap jujur dan tulus di hadapan Tuhan serta dilaksanakan secara bertanggung jawab. Tidak pura-pura; tidak abstrak. Inilah yang terlihat dalam hubungan dengan visi yang ditunjukkan oleh Nehemia. Visi dan tekad Nehemia untuk membangun tembok Yerusalem terangkum dalam pernyataannya, "Allah semesta langit, Dialah yang membuat kami berhasil! Kami, hamba-hamba-Nya, telah siap untuk membangun" (ayat 8). Dari ayat ini memperlihatkan semangat optimisme Nehemia. Ia tidak peduli dengan derasnya pesimistis yang dilontarkan oleh orang-orang yang berada di sekelilingnya. Semangat inilah yang seharusnya diejawantahkan dalam upaya membangun dan memperkuat visi dan misi PTKKI.

Untuk memahami pernyataan iman dari Nehemia, ada tiga prinsip utama yang menyebabkan visinya terlaksana, antara lain: Pertama, ia memiliki landasan yang kuat di dalam iman dan keyakinannya kepada Tuhan sehingga ia memulai dan mengawali dengan Tuhan (Ibrani: lakham elohe hashamayim). Kedekatan dan keharmonisan hubungan dengan Tuhanlah yang menyebabkan Nehemia berhasil. Tidak hanya itu, kesetiaan Nehemia kepada hukum Tuhan melalui hukum Taurat menyebabkan terjadinya perubahan kutuk menjadi berkat (Pasal 13). Proses mengawali dengan Tuhan adalah alkitabiah dan urgen. Kedua, kesadarannya sebagai hamba Allah. Nehemia mengakui dan menyadari peran dan tugasnya sebagai hamba kepada Allah. Karena itu, ia menyatakan bahwa "kami hamba-hamba-Nya" (Ibrani: avadav ebed). Hanya dengan kesadaran sebagai hamba, ia mampu berendah hati dan melayani dengan tulus.

Ketersalingan melayani menjadi urgen dalam segala hal termasuk pengurusan rumah besar melalui wadah Badan Musyawarah Perguruan Tinggi Keagamaan Kristen Indonesia (BMPTKKI) yang telah dilahirkan dan disahkan di Bali pada bulan Maret 2019

${ }^{7}$ Elia Tambunan, "GERAKAN TRANSNASIONAL KRISTEN: Wajah Ekonomi-Politik Agama dan Pendidikan di Indonesia” 1, no. 1 (2019): 1-17, https://ojsjireh.org/index.php/jireh/article/view/4/10. 
yang lalu. Di dalam rumah besar ini akan memberi ruang terbuka kepada PTKKI untuk saling mengisi dan berbagi. Perjuangan PTKKI untuk terus membenahi diri adalah perjuangan yang memerlukan semangat kebersamaan. Ketiga, keyakinan dan komitmen untuk bangkit serta membangun. Dalam teks asli bahasa Ibrani, frasa "telah siap untuk membangun" menggunakan kata "nakom \& ubaninu". Kata "nakom" dan "ubaninu" adalah dua kata yang saling mengisi. "Nakom" artinya "arise/bangkit" dan "ubaninu" artinya "build/rebuild/membangun." Karena itu, lebih tepat terjemahan bahasa Inggris King James Version dan New American Standar Bible yang menggunakan kata "will arise and build." Dari pengertian ini, tidaklah berlebihan bila menyatakan bahwa seseorang yang membangun sebuah proyek monumental mesti bangkit terlebih dahulu. Kebangkitan ini dapat berupa kebersediaan untuk diubahkan atau bangkit dari kematian hati nurani; bangkit dari kebodohan; bangkit dari cengkraman lingkungan; bangkit dari keterpurukan; bangkit dari keegoisan dan rela bermetamorfosis, dan lain-lain. Semangat membangun boleh-boleh saja, tetapi kesadaran kebangkitan terlebih dahulu (nakom) harus menjadi urutan prioritas.

Prinsip pengenalan terhadap permasalahan dalam sebuah kajian ilmiah sangat diperlukan. Inilah yang pertama dapat diamati dalam kepemimpinan Nehemia. Nehemia tidak hanya berkompeten mewujudkan apa yang akan dikerjakannya secara profesional tetapi juga memulai segala sesuatu dengan memastikan duduknya persoalan. Dalam teori penelitian, seseorang yang membangun teori dan menemukan hal-hal yang baru apabila ia telah merumuskan permasalahan terlebih dahulu. Dalam konteks ini, penulis menemukan bahwa melalui Hanani, salah seorang saudara dari Yehuda, Nehemia mengidentifikasi persoalan dengan menanyakan tentang orang-orang Yahudi yang terluput dan yang terhindar dari penawanan dan tentang Yerusalem. Nehemia mendapatkan laporan dari Hanani dan kawan-kawan bahwa persoalan tinggal tunggal sehingga ia memetakan langkah yang akan ditempuh sesuai dengan apa yang sedang terjadi di sana. Dari laporan Hanani dan kawan-kawannya tersebut ia mendapatkan empat permasalahan: Pertama, bahwa orangorang yang tinggal di Yerusalem, yang terhindar dari penawawan, sedang dalam kesukaran besar. Kedua, mereka dalam keadaan tercela. Ketiga, tembok Yerusalem telah terbongkar. Keempat, pintu-pintu gerbang telah terbakar. Ini data dan fakta yang diketahui oleh Nehemia sehingga ia mencurahkan segenap kekuatan bersama seluruh komponen masyarakat bergerak untuk membangun.

Dalam konteks PTKKI, perlu menyadari betapa kompleksnya persoalan yang sedang dihadapi. Pada sisi lain, sedang diperhadapkan pada banyak dilema, baik secara internal (konstituen/stakeholder) maupun secara eksternal. Secara internal, perlu menyadari bahwa semangat kebersatuan sebagai bagian dari Tubuh Kristus di akhir zaman ini terasa mulai hampa dan dangkal. Masing-masing ada kecenderungan mencari kenyamanan diri sendiri. Secara eksternal, regulasi-regulasi yang diberlakukan yang beragam dan cenderung berubah-ubah menjadi momok tersendiri bagi PTKKI termasuk kehadiran Peraturan Pemerintah (PP) No. 46 Tahun 2019 tentang Pendidikan Tinggi Keagamaan yang baru saja diundangkan oleh pemerintah pada tanggal 3 Juli 2019 terutama berkaitan dengan urusan Jabatan Fungsional (Jafung) dosen, dari Asisten Ahli sampai Profesor. Apakah PP ini memberi angin segar bagi PTKKI atau justru semakin memperbesar tanda tanya.

Salah satu kekuatan dari kepemimpinan Nehemia adalah memadukan segala kekuatan untuk mencapai target. Dalam kaitan ini, Thomas membandingkan bahwa Nehemia lebih sekuler dibandingkan Ezra yang terfokus dengan mengembalikan peribadatan orang Yahudi. ${ }^{8}$ Perlu dipahami bahwa bekerja adalah ibadah, maka

${ }^{8}$ Christopher H. Thomas et al., "Fluid Leadership in Dynamic Contexts: A Qualitative Comparative Analysis of the Biblical Account of Nehemiah," Journal of Management History 21, no. 1 (January 12, 2015): 98-113, https:/ / doi.org/10.1108/JMH-03-2013-0021. 
sesungguhnya Nehemia telah mampu menerjemahkan pengertian ibadat itu secara alkitabiah. Hal ini menjadi menarik ketika dalam waktu yang relatif singkat, yaitu selama 52 hari, tembok Yerusalem terbangun. Pencapaian target seperti ini merupakan bagian strategi yang mesti dihadirkan dalam kepemimpinan. Sekalipun ilmu tentang kepemimpinan pada zaman itu belum seperti perkembangan sekarang, tetapi Nehemia menggunakan unsurunsur pendekatan SMART (Specific/spesifik/jelas, Measurable/terukur, Attainable/dapat dicapai, Realistics/Relevant/realistis, dan Time Bounded/kurun waktu) yang mendorong untuk mengukur arah atau dinamika pergerakan tujuan yang sedang digumuli. Seperti dilaporkan dalam pasal 6 memperlihatkan kekuatan kemampuan manajerialnya sehingga pembangunan tembok Yerusalem selesai secara sempurna. Salah satu media pengukur dalam pencapaian tujuan di sini adalah "Time Bounded"yaitu program perencanaan yang berbasis waktu, terjawab secara nyata dalam pengalaman Nehemia. Secara khusus di dalam ayat 15 melaporkan bahwa "Maka selesailah tembok itu pada tanggal dua puluh lima bulan Elul, dalam waktu lima puluh dua hari." Ini merupakan waktu yang sangat singkat untuk mengerjakan proyek yang sangat besar. Hal ini tidak terlepas dari upaya menerjemahkan pentingnya batas waktu sehingga pekerjaan terukur dan efektif.

\section{Fungsi Spiritualitas dalam Kepemimpinan Nehemia}

Upaya memperjelas visi Nehemia guna membangun tembok Yerusalem dan memperbaiki atau mengganti pintu-pintu yang terbakar dimulai dengan sikap dan tindakan yang sangat manusiawi. Sikap dan tindakan manusiawi ini diikuti dengan upaya-upaya strategis untuk mencapai tujuan yang dicanangkannya sekalipun mengandung risiko. Ada beberapa sikap, prinsip, dan karakter yang perlu ditiru dari Nehemia dan kepemimpinannya, sebagai berikut:

\section{Duduk Menangis: Air Mata}

Dalam ayat $4 \mathrm{~b}$, Nehemia menangis (Ibrani: bakah). Tindakan menangis umumnya diikuti dengan air mata sebagai bukti kesungguhan. Ini sesungguhnya merupakan sikap terhadap penerimaan diri sebagai makhluk ciptaan Allah yang mulia, yang diperlengkapinya dengan natur berperasaan. Nehemia tidak menyembunyikan perasaannya baik di hadapan Tuhan maupun di hadapan manusia. Hal ini juga terungkap melalui kisah pada pasal 2 yang mengungkapkan tentang perasaannya di hadapan raja Artahsasta. Secara manusia, ia menunjukkan sikap bermuram muka karena kesedihan yang mendalam (ayat 13). Muram muka tidak identik dengan sakit. Hal ini mampu dibedakan oleh raja. Ia tentu tahu mana yang namanya sedih dan mana yang namanya sakit. Lebih menarik lagi ketika Nehemia memberi penegasan kepada raja tentang apa yang sedang dihadapinya. Nehemia berkata, "Bagaimana mukaku tidak akan muram, kalau kota, tempat pekuburan nenek moyangku, telah menjadi reruntuhan dan pintu-pintu gerbangnya habis dimakan api" (ayat 3). Ini merupakan alasan yang jujur dan paling mendasar bagi Nehemia yang disampaikannya kepada raja. Hal ini memperjelas sisi kemanusiaannya.

Tuhan menciptakan manusia dengan sempurna dalam segala keterbatasannya sebagai ciptaan. Dalam kitab Nehemia memperlihatkan sesungguhnya siapa manusia itu dan segala sifatnya yang original. Manusia mendapatkan berkat ekstraordinari atau privilese yaitu natur konstitusional manusia yang berkaitan erat dengan pikiran atau akal, perasaan, hati, roh, dan jiwa. Natur-natur ini menjadi bagian yang tidak terlepas dari anugerah Sang Pencipta manusia, yaitu Allah. Karena itu, tindakan menangis adalah salah satu perangkat yang disiapkan oleh Allah untuk dipakai oleh manusia. Dengan menangis, beban jiwa menjadi ringan. Dengan menangis manusia menjadi sehat. Tentu, menangis tidak sama dengan cengeng karena cengeng adalah tangisan yang cenderung negatif. Nehemia menangis karena sungguh-sungguh, serius, dan mau mewujudkan visinya secara nyata. 


\section{Berkabung}

Fakta kedua yang disebutkan dalam ayat 4c bahwa Nehemia berkabung (Ibrani: abal) karena kondisi Yerusalem. Kata "abal" ada hubungannya dengan dukacita yang mendalam. Kitab Nehemia menyaksikan bahwa Nehemia sendiri berkabung selama beberapa hari. Artinya, ia menggunakan cukup lama waktu untuk berkabung. Karena itu, secara tidak langsung, Nehemia sedang menyatakan kepada pembaca bahwa tembok Yerusalem dan pintu-pintu gerbangnya sama nilainya atau sama pentingnya dengan kematian sehingga melibatkan emosi perkabungan yang sangat kuat. Artinya, persoalan tembok Yerusalem dan pintu-pintu gerbang yang terbakar sangatlah serius di mata Nehemia.

Tindakan berkabung umumnya diikuti dengan penggunaan kain kabung dan tanah yang diletakkan di bagian kepala. Perlu dipahami bahwa kain kabung adalah pakaian yang dipakai untuk menunjukkan pertobatan yang umumnya dibuat dari rambut. Menaruh tanah di kepala merupakan tanda kesedihan yang amat mendalam. Alkitab menjelaskan bahwa kesedihan yang amat mendalam inilah sehingga doanya berkenan kepada Allah.

\section{Berpuasa}

Dalam ayat 4d menyatakan bahwa Nehemia berpuasa (Ibrani: tsum) sebagai tanda bahwa pergumulannya tentang pembangunan tembok Yerusalem adalah sangat serius dan betul-betul memerlukan pertolongan Tuhan. Alkitab mencatat bahwa tindakan berpuasa adalah tindakan yang tetap relevan dengan kehidupan orang percaya. Pada umumnya, kegiatan berpuasa dilakukan pada masa-masa genting. Orang-orang Israel berpuasa agar mengingat bahwa mereka tidak sempurna dan membutuhkan pengampunan dan hikmat dari Allah. Orang-orang yang melakukan perjalanan ke Yerusalem berpuasa untuk menunjukkan bahwa mereka sungguh-sungguh mengandalkan bantuan Allah.

Kata "puasa" muncul pada pasal 9:1 sesudah perayaan Pondok Daun. Nehemia menulis bahwa "Pada hari yang kedua puluh empat bulan itu berkumpullah orang Israel dan berpuasa dengan mengenakan kain kabung dan dengan tanah di kepala." Berhubungan dengan kegiatan puasa dalam pasal 9:1, The Cyclififfe Bible Commentary menjelaskan bahwa dalam konteks pasal 8:8 memperlihatkan bahwa bangsa itu menyisihkan suasana sukacita dan kebahagiaan mereka untuk mengaku secara umum di hadapan Allah tentang hebatnya dosa-dosa mereka serta penyesalan mereka.

\section{Berdoa}

Tindakan terakhir yang dilakukan oleh Nehemia dalam ayat 4e adalah berdoa (Ibrani: palal). Kata "palal" mengandung pengertian penyerahan diri total agar diintervensi oleh Allah. Doa adalah permohonan yang mengandung harapan, permintaan, dan pujian kepada Tuhan. Berdoa mengandung nilai penyerahan diri penuh karena keterbatasan, karena dosa, karena kuasa kejahatan dari iblis. Banyak pakar mendefinisikan tentang doa. Ada yang menyatakan bahwa doa adalah nafas hidup. Artinya, tanpa berdoa secara esensi berarti hidup sudah mati. Ada yang menyatakan bahwa doa adalah peluang anugerah di mana Allah membuka dirinya untuk mendengar umat-Nya. Namun, bagi penulis mengartikan bahwa doa adalah komunikasi timbal-balik dengan Tuhan yang dibangun atas ketaatan penuh kepada-Nya.

Keseriusan Nehemia berdoa kepada Tuhan terlihat dalam konten doanya. Dalam doanya ia melibatkan orang lain. Unsur-unsur yang terdapat di dalam doa Nehemia adalah pujian kepada Allah semesta langit; keyakinan mendasar kepada Allah yang mahabesar, dan dahsyat. Ia sangat yakin tentang janji, kasih, dan kesetiaan Allah. Pada sisi lain, ayat 5 juga menyuguhkan informasi bahwa Nehemia berdoa siang dan malam. Artinya, doa bagi Nehemia merupakan bagian yang sangat penting. Hal lain yang ditekankan dalam doa 
Nehemia adalah pengakuan dosa atau kesalahan baik yang dilakukan oleh Nehemia sendiri, kaum keluarganya, maupun orang Israel sendiri.

\section{Fungsi Manajemen dalam Kepemimpinan Nehemia Manajemen Pengembangan Sumber Daya Manusia}

Nehemia memiliki kemampuan manajemen sumber daya manusia yang terlihat dalam seluruh kegiatan yang dilakukannya sejak awal. Hal ini dibuktikan dengan kemampuan menggerakkan seluruh umat untuk bersama-sama membangun. Pernyataan umat yang tersurat di dalam pasal 1 memberi sinyal kuat tentang kemampuan Nehemia memanajemeni sumber daya yang ada dan tersedia.

Ketika Nehemia telah berada di Yerusalem seperti dilaporkan pada pasal 2, ia bangun pada malam hari bersama-sama dengan beberapa orang saja. Tidak banyak. Namun, pada pasal 2 ayat 17 menyemangatkan orang Yahudi, para imam, pemuka agama, penguasa, dan para petugas lainnya agar membangun tembok Yerusalem karena ada kemalangan yang sedang terjadi dan sedang dialami. Dalam pasal 3 memperlihatkan para peserta dalam pembangunan dengan melibatkan imam besar dan para imam lainnya. Tidak hanya itu, pelibatan raja Artahsasta pun dalam mega proyek tersebut terlihat dengan jelas.

\section{Manajemen Relasional}

Kemampuan kepemimpinan Nehemia telah teruji dan dicatat dalam sejarah. Ia tidak hanya cakap memimpin dalam skala kecil tetapi juga ia cakap memimpin dalam skala besar. Pengangkatannya sebagai Bupati Yehuda, mengindikasikan bahwa ia memiliki karunia kepemimpinan yang mumpuni. Jabatannya terus naik karena telah setia dan cakap melakukan tugasnya dengan baik pada saat ia mengurus minuman raja. Ia tetap naik dan bukan turun.

Terkait dengan strategi, Nehemia membangun hubungan yang baik dengan raja. Ia mempertahankan integritas sehingga ia tidak memanfaatkan dan memanipulasi hubungan. Mengalir apa adanya. Tatkala ia melakukan perjalanan menuju Yerusalem, ia memperlengkapi dirinya dengan surat-surat legal sebagai jembatan untuk berkomunikasi dengan pemimpin lain; sebagai jembatan untuk mendapatkan dukungan/perlindungan; dan sebagai jembatan untuk mendapatkan bahan baku pembangunan, dan sebagainya.

Selain membangun hubungan yang baik dengan raja juga Nehemia membangun hubungan harmonis dengan seluruh umat-masyarakat. Ia sangat sadar bahwa tanpa dukungan masyarakat/bawahan, proyek besar tidak akan berjalan baik. Ia membangun semangat optimisme yang tinggi sehingga masyarakat memberi dukungan penuh. Hal ini terlihat ketika Nehemia berbagi visi kepada seluruh umat di Yerusalem (Pasal 2:17) lalu seluruh umat berkomitmen dengan menyatakan, "Kami siap untuk membangun" (ayat 18). Semangat juang dan optimisme yang tinggi yang dikobarkan oleh pemimpin yang diurapi akan memberikan dampak yang luar biasa bagi pencapaian visi.

Strategi lain yang ditunjukkan oleh Nehemia adalah ketika ia bangun pada malam hari untuk melakukan penyelidikan/survei. Di dalam pasal 2:12 melaporkan bahwa ia bangun bersama-sama dengan beberapa orang saja yang menyertainya. Kemudian ia menyatakan bahwa ia tidak memberitahukan kepada siapa pun rencana yang akan dilakukannya di Yerusalem seperti yang ditaruh oleh Tuhan di dalam hatinya. Hal ini memberi petunjuk kepada para pemimpin - bahwa dalam kondisi tertentu - harus menjaga kerahasiaan. Menurut tafsiran Wycliffe, tindakan seperti ini adalah "bijaksana, mengingat banyaknya musuh di sekitar itu, untuk menjaga agar rencananya tetap rahasia sampai ia bisa mengetahui dengan pasti keseriusan tugas itu."9 Kebenaran ini menjelaskan bahwa ada

9Pfeiffer and Harrison, The Wycliffe Bible Commentary: Tafsiran Alkitab Wycliffe, 1167-1168. 
hal-hal tertentu di dalam kepemimpinan yang mesti dijaga kerahasiaannya sebelum menjadi jelas dan terang. Pun kalau telah menjadi terang dan jelas, prinsip kerahasiaan tetap berjalan. Banyak pemimpin menjadi gagal dalam kepemimpinannya karena tidak menahan diri untuk menjaga kerahasiaan dalam proses kepemimpinannya. Sikap terlalu cepat 'bocor' akan mengganggu dan merusak relasi-relasi.

\section{Manajemen Konflik}

Sebagai seorang pemimpin, harus mampu memanajemeni konflik atau persoalan yang muncul baik yang datang dari internal maupun eksternal. Bagi Wirawan, konflik adalah "proses pertentangan yang diekspresikan di antara dua atau lebih yang saling tergantung mengenai objek konflik, menggunakan pola perilaku dan interaksi konflik yang menghasilkan keluaran konflik."10 Salah satu hal penting yang perlu dimengerti secara sadar bahwa setiap organisasi pasti terjadi konflik. Hal ini, tentu konflik bisa positif dan juga bisa negatif; bergantung pada substansi persoalan dan upaya pemimpin menyelesaikannya.

Konflik yang terjadi dalam pengalaman kepemimpinan Nehemia beragam dan kompleks. Secara eksternal, gempuran olokan, hinaan, dan tuduhan dari kelompok Sanbalat, orang Horon, dan Tobia, orang Amon, Gesyem, orang Arab bukanlah penghalang bagi Nehemia. Justru dalam kondisi seperti ini, ia memperlihat kewibawaannya, imannya, dan semangatnya kepada orang-orang itu. Kondisi ini, tidak membuyarkan semangat juangnya membangun tembok Yerusalem bersama seluruh masyarakat/orang-orang Yahudi (bandingkan Pasal 2:20 dan Pasal 4). Konflik secara internal juga muncul. Munculnya keluhan dari rakyat, pihak para istri, dan keluarga menjadi persoalan tersendiri. Demo urusan hidup, makan, minum, urusan pajak, dan lain-lain disampaikan kepada Nehemia secara terbuka. Namun, Nehemia memiliki kharisma sebagai seorang pemimpin. Ketegasan dan keberanian tanpa kompromi yang beralasan, menjadikannya terangkat menjadi pemimpin yang berhasil (bandingkan Pasal 5-6).

\section{Manajemen Etis-Moral}

Nehemia adalah sosok pemimpin yang beretika. Ia sangat profesional. Ia memiliki sikap yang terpuji. Ia sangat menghormati/respek kepada pemimpinnya (raja Artahsasta). Pernyataannya pada pasal 2:3a "Hiduplah raja untuk selamanya" menekankan tentang kualitas penghormatannya kepada pemimpinnya tanpa basa-basi. Hal yang lebih menarik lagi adalah kesadarannya terhadap kekuasaan raja. Sesungguhnya ia pasti tahu bahwa ia sedang melihat tanda-tanda kebaikan raja. Namun, ia tidak memanfaatkan kesempatan secara arogan. Bahkan, ketika ada peluang pertanyaan raja untuk mengungkapkan keinginannya, ia menyatakan, "Jika raja menganggap baik dan berkenan kepada hambamu ini, utuslah aku ke Yehuda, ke kota pekuburan nenek moyangku, supaya aku membangunnya kembali" (2:5).

Pengalaman yang sama ketika ia juga meminta surat-surat legal untuk kebutuhan perjalanannya, Nehemia berkata, "Jika raja mengganggap baik, berikanlah aku surat-surat bagi bupati-bupati di daerah seberang sungai Efrat, supaya mereka memperolehkan aku lalu sampai aku tiba di Yehuda dan juga surat kepada Asaf, pengawas taman raja, supaya dia memberikan aku kayu untuk memasang balok-balok pada pintu-pintu gerbang di banteng bait suci, untuk tembok kota dan untuk rumah yang akan kudiami" (ayat 7-8). Kejujurannya terverifikasi ketika raja memberi perhatian penuh pada persoalan yang sedang digumuli oleh Nehemia dan mengabulkan permintaannya. Satu pelajaran penting dalam interaksi timbal balik antara raja dengan Nehemia bahwa tidak semua yang baik menurut kita, belum tentu baik atau kompatibel menurut orang lain. Tidak semua yang baik dalam perspektif

${ }^{10}$ Ibid. 
kita, belum tentu baik untuk orang lain. Karena itu, semestinya kita memberi ruang yang terbuka luas kepada orang lain atau atasan untuk mengambil keputusan yang bijaksana dan baik berdasarkan pertimbangan yang diajukan. Keputusan yang baik akan terjadi apabila telah melalui proses pertimbangan yang matang.

\section{Implikasi}

Gaya kepemimpinan Nehemia sangat relevan dengan konteks zaman yang sedang dihadapi saat ini yaitu perlunya keandalan kecepatan dalam segala hal. Karakter kepemimpinan Nehemia berimplikasi pada kemajuan pelayanan yang sedang diemban di lingkungan PTKKI karena berhubungan dengan banyak hal. PTKKI perlu berbenah diri secara terbuka. Perlu keseriusan untuk menghadapi berbagai persoalan-persoalan yang muncul misalnya persoalan akreditasi, jabatan fungsional atau kepangkatan, sertifikasi pendidik, sistem penjaminan mutu internal, termasuk audit mutu internal, dan sejumlah persoalan lain yang perlu penanganan secara cepat dan kreatif.

Harus diakui bahwa pergumulan PTKKI sangatlah beragam dan kompleks. Untuk mengatasinya, memerlukan semangat kerja sama yang terkoordinasi dan terorganisasi secara profesional. Kesatuan dan persatuan hati secara konkrit di tengah-tengah perubahan sangatlah dibutuhkan. Ada baiknya memperbanyak kerja daripada memperbanyak bicara; apalagi saling menjatuhkan satu dengan lainnya. Tindakan ketersalingan untuk mengangkat dan membantu sangatlah diperlukan. Kesadaran penuh terhadap apa yang menjadi kekuatan, kelemahan, kesempatan, dan tantangan serta rintangan juga merupakan kekuatan untuk membangun PTKKI. Tentu, dalam konteks ini, pemimpin memiliki andil yang sangat besar untuk mencapai tujuan organisasi.

Perlu dipahami bahwa seorang pemimpin yang baik, ia mesti menunjukkan bahwa ia adalah pemimpin yang baik. Pemimpin yang baik adalah seseorang yang menyadari panggilan, fungsi, dan tanggung jawabnya sebagai seorang pemimpin, baik dalam skala "pemimpin kecil' maupun dalam skala "pemimpin besar." Rosalynn Carter, mantan Ibu Negara Amerika Serikat memberi perbedaan signifikanantara pemimpin kerdil dengan pemimpin besar. Perbedaan ini dikutip oleh Maxwell dengan menyatakan bahwa, "Seorang pemimpin kerdil membawa orang lain ke tempat yang mereka inginkan, sementara seorang pemimpin besar membawa orang lain ke tempat yang belum tentu mereka inginkan, tetapi mereka harus tuju."11

Implikasi dari pernyataan Rosalynn meneguhkan beberapa prinsip tentang pemimpin. Pertama, bahwa seorang pemimpin perlu memiliki visi yang besar untuk mencapai hal-hal besar. Kedua, seorang pemimpin perlu menyadari bahwa pada dirinya ada kuasa (kuasa kepemimpinan) sehingga menciptakan kemandirian dalam mengambil keputusan-keputusan strategis terutama dalam hal pengelolaan sumber daya manusia yang efektif. Ketiga, seorang pemimpin perlu memiliki sasaran atau target yang jelas walaupun disertai dengan konsekuensi yang tidak sedikit seperti olokan, bantahan atau penolakan. Dalam segala kondisi, pemimpin harus berdampak dan berpengaruh. Menurut Hikijuluw dan Sukarto menjelaskan bahwa pemimpin yang berdampak adalah "orang yang menggunakan pengaruhnya untuk mentransformasi dunia di sekitar mereka dan memberikan dampak yang baik sebagai hasil kepemimpinan mereka. Dampak seorang pemimpin menggambarkan atau merefleksikan kepemimpinannya. Kepemimpinan yang berjalan dengan baik adalah hasil dari pemimpin yang baik." Hal ini juga yang terlihat secara menyeluruh dalam kepemimpinan Nehemia yang merefleksikan bahwa kepemimpinannya adalah kepemimpinan yang baik dan berhasil.

\footnotetext{
${ }^{11}$ John C. Maxwell, Semua Orang Bisa Memimpin (Jakarta: BPK Gunung Mulia, 2017).
} 


\section{Rekomendasi untuk Penelitian Lanjut}

Penulis sadar bahwa kitab Nehemia sangat sarat dengan nilai-nilai kepemimpinan. Tidak semua mengupas tentang kepemimpinannya dalam artikel ini. Hanya sebagian kecil yang dianggap menjadi titik perhatian penulis terutama berkaitan dengan karakternya tatkala menghadapi rusaknya tembok Yerusalem dan terbakarnya pintu-pintu gerbang Yerusalem. Reaksi awal dari Nehemia dan keyakinannya kepada Allah sangat inspiratif. Tentu, sangat banyak nilai yang berkaitan dengan kepribadiannya yang perlu dikupas agar memperkaya pemahaman pembaca. Ada sejumlah karakter dari kepemimpinannya yang perlu ditiru dan dikembangkan. Karena itu, diperlukan penelitian lebih lanjut secara mendetail dan komprehensif.

\section{Kesimpulan}

Nehemia memiliki keunggulan yang patut diteladani. Ia salah seorang guru atau dosen kepemimpinan di dalam Perjanjian Lama. Ia memiliki sejumlah kapabilitas atau kepintaran mumpuni. Ia memiliki kepintaran spiritualitas, kepintaran intelektual atau hikmat, kepintaran sosial, kepintaran relasional, kepintaran etis, kepintaran strategis, kepintaran manajerial, dan lain-lain, yang meneguhkannya sebagai sebagai seorang pemimpin yang kompeten atau visioner. Ia adalah sumber inspirasi para pemimpin di segala zaman dan waktu. Ia adalah sumber rujukan kepemimpinan dalam kepemimpinan modern. Ia adalah pemimpin yang berdampak luas bagi orang-orang yang dipimpinnya.

Badan Musyawarah Perguruan Tinggi Keagamaan Kristen di Indonesia (BMPTKKI) adalah wadah atau rumah besar bersama sebagai tempat yang tepat untuk menggumuli dan memikirkan langkah-langkah pengembangan PTKKI dalam konteks institusi pendidikan sekarang ini. Konferensi perdana dari rumah besar ini telah dilaksanakan pada tanggal 28-30 Agustus 2019 di Jakarta. Bertolak dari ilmu kepemimpinan Nehemia, mesti jujur menyatakan bahwa sebagian besar PTKKI, saat ini sedang mengalami beragam persoalan kepemimpinan. Kepemimpinannya yang sarat dengan nilai dan makna memberi ruang bagi PTKKI untuk berbenah diri. Karena itu, melalui kepemimpinan Nehemia dapat belajar berbagai hal terutama dalam hubungannya dengan pengabdian PTKKI. Semestinya menggumuli secara serius hal-hal yang berkaitan dengan peraturan dan regulasi terbarukan tentang pendidikan. Tentu saja, tidak ada jalan instan kecuali berbenah diri pada tataran yang lebih baik dan benar.

Mencapai keberhasilan dalam tugas dan pengabdian di PTKKI tidak hanya cukup aspek spiritualitas semata, akan tetapi diperlukan semangat kebersamaan dengan melibatkan institusi atau organisasi lain. Tindakan dan gaya tradisional dan terkesan sendiri-sendiri memang akan menguras energi. PTKKI melalui BMPTKKI perlu bersinergi untuk menemukan solusi guna mengatasi berbagai kesulitan yang sedang terjadi. PTKKI sebaiknya menjadi yang terdepan dalam memperjuangkan hak-hak konstitusionalnya dan tentu optimis meraih keberhasilan seperti yang dipraktikkan oleh Nehemia.

\section{Rujukan}

Alkitab Edisi Studi. Jakarta: Lembaga Alkitab Indonesia, 2014.

Darmaputera, Eka. 365 Anak Tangga Menuju Hidup Berkemenangan. Jakarta: BPK Gunung Mulia, 2005.

Lumintang, Stevri Indra. Theology: The Queen of Science $\mathcal{E}$ The Master of Philosophy. Jakarta: Geneva Insani Indonesia, 2015.

Maxwell, John C. Semua Orang Bisa Memimpin. Jakarta: BPK Gunung Mulia, 2017.

Nikijuluw, Victor P. H., and Aristarchus Sukarto. Kepemimpinan Di Bumi Baru: Menjadi Pemimpin Kristiani Di Tengah Dunia Yang Terus Berubah. Jakarta: Perkantas, 2014. 
Pfeiffer, Charles F., and Everett F. Harrison. The Wycliffe Bible Commentary: Tafsiran Alkitab Wycliffe. Malang: Gandum Mas, 2007.

Sendjaya. Kepemimpinan Kristen: Konsep, Karakter, Kompetensi: Menjadi Pemimpin Kristen Yang Efektif Di Tengah Tantangan Arus Zaman. Yogyakarta: Kairos, 2004.

Tambunan, Elia. “GERAKAN TRANSNASIONAL KRISTEN: Wajah Ekonomi-Politik Agama dan Pendidikan di Indonesia" 1, no. 1 (2019): 1-17. https://ojsjireh.org/index.php/jireh/article/view/4/10.

Thomas, Christopher H., Andrew S. Hebdon, Milorad M. Novicevic, and Mario J. Hayek. "Fluid Leadership in Dynamic Contexts: A Qualitative Comparative Analysis of the Biblical Account of Nehemiah." Journal of Management History 21, no. 1 (January 12, 2015): 98-113. https://doi.org/10.1108/JMH-03-2013-0021.

Tomatala, Yakob. Anda Juga Bisa Menjadi Pemimpin Visioner. Jakarta: YT Leadership Foundation, 2007.

Tong, Stephen. Iman, Rasio, Dan Kebenaran. Jakarta: Penerbit Momentum, 2009.

Wirawan. Kepemimpinan: Teori, Psikologi, Perilaku Organisasi, Aplikasi, Dan Penelitian. Jakarta: RajaGrafindo Persada, 2018. 